\title{
THE ROLE OF KOREAN COLLECTIVISM IN SOUTH KOREA'S INDUSTRIALIZATION PROCESS
}

\author{
Tan Soo Kee
}

\begin{abstract}
Traditionally, Korean leadership has been perceived as hierarchically authoritative, paternalistic, nationalistic and as having group consciousness. Unlike western societies which promotes freedom and human rights, Korean society has been dominated by values of obligation, duty and group harmony. By focusing on the role of national leadership and Korean entrepreneurship, this paper examines how the collectivist values have been incorporated in to the national ideology, governance principles as well as Korean management system. Park Chung Hee's leadership and Korean chaebol founders are the main subjects of discussion in this paper, since they have laid the foundations of Korean industries as well as are well known for their collectivist characteristics. This study shows that the collectivist values worked very well in the early industrialization process of Korea, which helped to produce disciplined and determined work forces. By sacrificing worker's welfare, Korean industrial players were able to produce goods and services through relatively lower costs, which enabled Korean firms to be competitive in the international market. Nevertheless, after the Korean economy entered into the stage of innovation-driven, the rigidity of the collectivist culture began to undermine economic performance. In sum, collectivism worked well in the initial stages of industrialization; however it has not guaranteed better innovation as what had been enjoyed in western individualist cultures.
\end{abstract}

Keywords; Collectivist Culture, Patriotism, Entrepreneurship, Park Chung Hee

\section{Introduction}

Korea has been a highly structured and collective society characterized by strong social pressures to act, conform and obey. ${ }^{1}$ The strong collectivism of Korea has not been merely influenced by Confucianism, but also contributed by its national education system and compulsory military training program. The Korean military training program, which subjects all male Koreans to a mandatory service of about two years has developed a collective and militaristic culture in majority of Korean work places. This is especially significant since male workers are the majority in the active workforce in Korea. Further, the militaristic system of governance dominated Korean ruling class from the 1960s to 1980s. The stress of "woori (we), one voice and one country" was not only the common slogan in public campaigns but also in private sector.

Several studies show that Korea is high in power distance and collectivism. ${ }^{2}$ The Korean leadership style has been perceived as autocratic and group focused, especially

1 J.F. Milliman, Y. M. Kim and M.A.V Glinow, "Hierarchical Advancement in Korean Chaebols: A Model and Research Agenda", Human Resource Management Review, Vol. 3, No. 4, 1993, pp 293-320.

2 G. Hofstede, "Culture's Consequences: Comparing Values, Behaviors, Institutions, And Organizations Across Nations. California: Sage Publication, 2001; R. House et al., Culture, Leadership, And Organizations: The Globe Study of 62 Societies, California: Sage Publications, 2004. 
during the early stages of industrialization. Several studies of Korean leadership suggests that it is hierarchically authoritative and paternalistic. ${ }^{3}$ Examples of this paternalistic hierarchical authority includes the former presidents of South Korea - Park Chung-Hee and Chun Doo Hwan, both characterized as dictators for their autocratic leadership. Although the hierarchical structure limits the flexibility of management, it can be argued that autocratic leadership allows for quick decision making. ${ }^{4}$ In the Korean management system, group consciousness is strongly emphasized and is held to be a critical value for many organizations. These strong collectivist values encourage strong Korean team spirit that drives performance. Collectivism equally fosters strong relationships where everyone takes responsibility for their fellow group members. ${ }^{5}$ The more collectivist a culture, the more likely workers accept such team-based work arrangements.

There are many stories extolling the virtues of Korea's strong collectivist culture and how it has contributed to their economy. One such story is that of Korea's POSCO steel company, which started with almost nothing in 1960s to become a world class steel company two decades later. Former POSCO president Park Tae-Joon, who has always emphasized patriotism with his famous motto "make steel, serve the country", stimulated the patriotic spirit of Korean workers across the country to work day and night for the benefit of Korea. The "make steel, serve the country" motto and "turn right" spirit, became the mental foundation of POSCO and bound every worker together when Park Tae-joon first set his company on its path to becoming an industrial giant. The 'turn right spirit expressed Park Tae-Joon's firm will to successfully build steelworks into an industrial giant. This was based on the sacrifice expected of POSCO board members, that they be willing to throw themselves into the Yeongil Bay if they did not succeed in meeting objectives. ${ }^{6}$ The success story of POSCO has earned Park Tae-Joon near legendary status from steel experts around the world. Today, POSCO steel is ranked as one of the top innovative companies in the world. The patriotism of its industry leaders and workers has built a strong hard-working culture that appreciates discipline and determination.

The patriotic spirit that makes a Korean willing to sacrifice for the country can be seen in society's general attitude. For example, in 2010, a 60 year old Korean man named Ahn Seung-pil won the largest jackpot ever at Kangwon Land Korea and he decided to donate the prize money (USD \$700,000) to the Korea Advance Institute of Science and Technology (KAIST). Ahn remarked,

After winning the money, I first though about donating it to help the unfortunate, but after watching a TV program emphasizing the importance of advanced science and technology to Koreas' future, I decided to give the money to KAIST. ${ }^{7}$

3 I.J Yang, "Jeong Exchange and Collective Leadership in Korean Organizations" Asia Pacific J. Manage, Vol. 23, 2006, pp 283-298.

4 I.J Yang, "Jeong Exchange and Collective Leadership in Korean Organizations" pp 283-298.

5 G. Hofstede, Culture's Consequences: International Differences in Work-Related Values, Newbury Park, CA: Sage, 1980.

6 "POSCO leadership Park Tae Joon", KBS World, 19 December 2011. Available from http:// world.kbs.co.kr/english/program/program_economyplus_detail.htm? $\mathrm{No}=3142$, accessed $30 \mathrm{June}$ 2012.

7 “Jackpot Winner Donates $\$ 700,000$ to KAIST. Korea Times, 17 May 2010, available from:http:/ / www.koreatimes.co.kr/www/news/nation/2010/05/117_66037.html, accessed 10 January 2011. 
KAIST is a graduate school specializing in science and engineering education and research. Due to the high volume of new patents being produced by KAIST, the school was ranked as one of top 100 innovators in the world in 2012 by Thomson Reuters. The generosity of Ahn in donating his prize money to KAIST is an expression of the collectivist spirit of South Korea and of the pervasiveness of their concern for research and development investment. With a populace willing to sacrifice personal benefits for national gain, it is easier for Korea to move forward as a nation on the collective shoulders of her people.

The Korean spirit of acting for the group and country was expressed perfectly when the currency crisis hit Korea in 1997. Korea witnessed corporate bankruptcies, malfunctioning of the banking and financial sectors, abrupt asset deflation, negative economic growth rates, high unemployment, growing homelessness and the Korean government nearly became bankrupt. In order to save the country, the Kim Dae Jung government ran a Gold Collection Campaign to collect funds to save the financial status of the state. Certainly this campaign would not have been successful without Korea's patriotic spirit. The number of people who participated in the campaign in over three months reached 3.49 million and the value of gold collected amounted to USD2.17 billion. ${ }^{8}$ On average, each household brought $65 \mathrm{~g}$ of gold to the bank to sell, under the pretext of rescuing the nation from a crisis. ${ }^{9}$ The strong sense of self-sacrifice and loyalty to firm and nation has enabled the Korean government to push national economic growth as a collective obligation and a civic duty. This explains how collectivism made the Korean economy more dynamic, particularly during the early stages of industrialization.

\section{Patriotism and Park Chung Hee's Leadership}

Several studies suggests that patriotism played a major part in the economic modernization and industrialization of Korea, especially in the initial stages of industrialization. ${ }^{10}$ The strong desire to serve and work for the country was particularly strong during Park Chung Hee's era from 1960s to 1970s. From top national leaders and entrepreneurs, to South Korean workers, patriotism and devotion to the country was strongly expressed. During Park Chung Hee's era, South Koreans were encouraged to commit themselves to national development by equating economic development with national goals. ${ }^{11}$ Government's role in particularly, was very essential in inspiring Korean collectivist spirit during 1960s-1970s. Under the Park Chung Hee's government, people were reminded everyday with slogans of collective goals of "kugwi sonyang" (enhancing national prestige), "kungnyok" (enhancing national strength) and "oehwa

8 G.S Park, Y.S Jang, and H. Y Lee, “The Interplay between Globalness and Localness: Korea's Globalization Revisited", International Journal of Comparative Sociology, Vol. 48, No. 4, 2007, pp 337-353.

9 S. D Kang, "Labour Relations in Korea between Crisis Management and Living Solidarity" Inter-Asia Cultural Studies, Vol.1, No.3, 2000, pp 393-407.

10 U.C Kim, "The Ideology of Modernization and Pursuit of Happiness", Korea Journal, September issue, 1986; E. Kim, and G. S Park, "Nationalism, Confucianism, Work Ethic and Industrialization in South Korea", Journal of Contemporary Asia, Vol.33.No.1, 2003.

11 E. Kim, and G. S Park, "Nationalism, Confucianism, Work Ethic and Industrialization in South Korea", Journal of Contemporary Asia, Vol.33.No.1, 2003. 
hoektuk" (earning foreign exchange). ${ }^{12}$ The campaigns were promoted through the wise use of mass media, including television, radio, newspapers and magazines.

Among Korean leaders, Park Chung Hee is recognized as Korea's most effective country chief who successfully transformed South Korean economy by reconstructing national culture, which Park called it as "human revolution". He stressed the need for collectivist mentality for achieving national strength, urging people to be diligent, independent and encouraged sacrificing one's own interest for national gains. When Korea was in extreme poverty and chaos, Park stated that,

A nationwide movement must be begun to train the people in the sound ethics required by democratic citizens... one might as well expect a rose to flower from a garbage box as expect democracy to succeed in Korea, it is our duty to make use of the garbage box full of past failures as fertilizer which will nurture a beautiful rose of democracy. ${ }^{13}$

Park's positive attitude of "we can do anything" and the expression jalsaraboja ( Let us have a better life) as well as the motto " the better the economy is, the better the life is for every worker" were government slogans which attempted to propagate positivity of industrial work and organization. ${ }^{14}$ To transform South Korean economy, Park Chung Hee believed that a cultural revolution was necessary in order to implant the spirit of being confident. Park stated that,

...we must reflect upon the evil legacies of our past history, slough way the factional consciousness inherited from the Yi dynasty, and the slavish mentality resulting from the Japanese colonial rule, and firmly establish a sound National ethics. Without a human revolution, social reconstruction is impossible.... a nationwide movement must be begun to train the people in the sound ethics required by democratic citizens. ${ }^{15}$

Through a national reformation campaign, Park launched the "national awakening" program to motivate Koreans. Industrial workers were described as "shu'chul pyong sha" (export warriors) to enable South Korea to achieve the "sonjin-guk" (developed nation) status. Park stressed that:

...when the interests of the whole are in conflict with the interest of a given individual, we must endeavor to seek agreement through the self-sacrifice and self-control of the individual. Such self-sacrifice and self-control in the interest of the whole is only common sense, and from the national stand point constitutes the national conscience. Only when common sense has been restored and national conscience revived can we realize social justice whereby the whole people can enjoy prosperity. ${ }^{16}$

Thus, national industrial policies were completely collectivistic and national interest was given top priority, issues of individual freedom and human rights were sidelined. For

12 U.C Kim, "The Ideology of Modernization and Pursuit of Happiness", Korea Journal, September issue, 1986.

13 C. H Park, Our Nation Path: Ideology of Social Reconstruction, Seoul: Hollym Corporation, 1970.

14 E. Kim, and G. S Park, "Nationalism, Confucianism, Work Ethic and Industrialization in South Korea", Journal of Contemporary Asia, Vol.33.No.1, 2003.

15 C. H Park, Our Nation Path: Ideology of Social Reconstruction, Seoul: Hollym Corporation, 1970.

16 C. H Park, Our Nation Path: Ideology of Social Reconstruction, Seoul: Hollym Corporation, 1970, p 32. 
instance, South Korean workers' welfare and rights were sacrificed to keep industrial costs lower, increase exports and help South Korean industrialists to be more cost competitive in the international market.

\title{
Sacrificing Workers' Welfare for Faster Growth of Korean Firms
}

Stressing the need for "self-sacrifice", Park used this principle to justify the nation's labour suppression policy, where Korean workers were required to work long hours with low wages, limited bargaining power and prohibition from questioning labourers' right. The main reason was to facilitate South Korean industrialists to produce goods and services at a lower cost and to expand the export market. Trade unions were totally banned and labourers' activities were controlled by the state in the form of direct intervention by the police and national security agencies. Such policies were favourable for employers but not for the employees. The Gyunghyang Daily News of 27 Oct 1970 described the following working condition in a textile factory,

\begin{abstract}
...Young girls are working in a small room as long as 16 hours a day, with extremely low wages and even industrial disease...the workplaces, which are smaller than eight sg $\mathrm{m}$, are so packed with 15 workers, sewing machines and other machinery that people can hardly move... the ceiling is just 1.5 meters, making the workers not able to stretch their waists... with two days off only in a month. ${ }^{17}$
\end{abstract}

This story describes the oppressive work environment of the textile industry where female workers were placed under the low-paid system. Even though workers continued to ask for wage rises and more holidays, most of the time it was rejected by the authority with government support. Another example tells how management authority justified its anti-labor policy by mentioning the importance of collectivistic spirit.

In January 20, 1964, when the KSEC union asked for a 4,500won raise at a LaborManagement Council meeting, the president of the company began by urging to the union representatives about the importance of raising efficiency and conforming to a diligent work ethic, which he concluded that "all the employees should tighten their belts" in the spirit of labor-management cooperation until 1966 in support of the nations' First Five-Year Plan for economic development. A company auditor also urged that: "We should not think of ourselves separately as union men or managers. We should worry together and try together to find solutions as members of one family". So Taewan, who represented the labor union protested, saying that in 1963 the company registered "net profit of 23 million won, which is enough to cover 100percent of the raise demanded by the union... It is essential to help workers who do hard physical labor on a diet of a 10-won piece of bread so that they can maintain their physical strength better." The "one-family" rhetoric notwithstanding, management merely repeated its emphasis on a diligent "working spirit" and ignoring the requirement by So Taewan. ${ }^{18}$

To Park Chung Hee, nothing was more urgent than solving the poverty problem. In facing the North Korean threat, Park was of the opinion that the South Korean economy

17 D. O Chang, Capitalist Development in Korea: Labour, Capital and the Myth of the Developmental State, Oxon: Routledge, 2009, p 98.

18 H.S Nahm, Building Ships, Building A Nation: Korea Democratic Unionism under Park Chung Hee, Seattle and London: University of Washington Press, 2009, p 92. 
must be developed in order to become a powerful nation. South Korea lacked capital and workers were told to endure the hardship associated with low incomes and poor working condition for the time being. Park's government was acted like the chief of industries, and entrepreneurs were like the captain of industries, while workers were described as "export warriors" (soochooljeonsa) or industrial soldiers (saneobyongsa) that carried the national task to achieve the nation's export target. In addition, corporate slogans, such as "Let's catch up with Japan", "Let's beat Japan" were also utilized by the government to motivate workers to work. ${ }^{19}$

In a collectivistic culture, fulfilling obligation to society is always more important than protecting human rights. In order to compete internationally, South Korean leadership believed that Korea must be able to price their products competitively. Therefore, workers were reminded that working in the industries was not only for self-survival but it was an obligation to help industries to grow, to strengthen Korean economic power. Collectivism and patriotism functioned as a national ideology in motivating laborers to work. Creating favorable conditions for rapid industrialization not only required cheap labour, but also the absence of labour disputes. Hence, Park's government prohibited union activities and suppressed collective bargaining.

After two decades of enforcing an "underpaid" system, Park successfully enhanced South Korean industries' competiveness in a short period of time; enabling local industries to substantially improve their image abroad. The labour intensive industries, such as footwear and textile industry, enjoyed fruitful results. Through cost competitiveness, Korean exports increased tremendously from USD55million in 1962 to USD17, 214 million in 1980, a 300 fold increase within 20 years. Korean workers certainly played a significant role through their accommodative behavior towards the government's policies of low wages, long working hours, high productivity and a bad work environment. In short, the collectivist culture functioned as a "hegemonic ideology" to legitimize state repression." 20

In the late 1970s, when Park Chung Hee was facing people's protest during the Yushin constitution, and issues of workers' rights, he again reminded his people about the importance of the collectivistic spirit.Park Chung Hee wrote that,

Whenever a society is given to extreme individual or collective rationalism and when such rationalism produces fragmented individualism, the resultant conflicts and confrontation degenerates into an uncontrollable state of chaos. Attempts by individuals or groups to maximize their immediate advantage may seem rational at some point, but when seen from a social point of view, they are not only irrational but sometimes become dangerous. ..It might result in a case of individual interest leading to a collective unhappiness... If a railway goes on strike, the foodstuff industry that depends on transportation is affected, which in turn causes problems at the consumers' table. Such interdependence lays an entire society vulnerable to collective action by any small group. No country in the world has enough resources and wealth to satisfy

19 E. Kim, and G. S Park, "Nationalism, Confucianism, Work Ethic and Industrialization in South Korea", Journal of Contemporary Asia, Vol.33.No.1, 2003, p 42.

20 N Loy, "Culture, Institution, and Economic Development in South Korea", 2008, Global and Strategies, available from: http:/ / journal.unair.ac.id, accessed 17 July 2013. 
everyone's demands. As a result, the government ends up satisfying one group at the expense of another. ${ }^{21}$

In Park Chung Hee's view, Korean industrialization need the people's collectivistic spirit, the "woori" culture must be promoted. Through the "woori" culture, Korean industries would be able to grow faster with the collective strength of its people. Eradicating poverty was important. Thus, the duty of helping oneself and helping others in making lives better in terms of economics was emphasized by Park. To strengthen the workers' commitment to work, Park urged them to work as if they owned the business, demanded workers to be as dedicated to the firm as they would be to their parents, and employers were requested to treat workers like members of their own family. Posters and brochures containing the work-exalting slogans could be found on walls in workplaces and on street billboards. Banners on the streets were to ensure that there everyone was made aware of the urgency of industrialization. ${ }^{22}$ Through the promotion of loyalty to firm and concept of paternalism, national campaigns successfully enhanced workers' work attitudes and performance. Loyalty to the firm made workers work hard and the cooperation spirit strengthened team power. It can be observed that the

Korean industrialization process is full of touching stories...Park Chung-hee went to
Germany to borrow funds, but the banks refused to lend Korea any money. Hearing
this, the Korean miners working there pledged their wages for the next 20 years as
collateral. Park and the miners cried together and Park returned home with the money.
In Vietnam, our young soldiers sent home all their dollar-denominated wages earned
in the bloody battlefields. The money was used well to invest in industrialization.
Young women from the country worked hard in factories and sweatshops, and many
labourers sweated on the construction sites of Middle East during the boom days...
there was a considerable consensus among the people about the national motto of
building the economy to lead better lives.

The story tells how the collectivistic spirit served as the mobilization source to make individuals willingly sideline their own goals. Both workers' voluntary participation in industrial work and the harmony in the workplace, which were two of the most essential factors in the nation's remarkable economic success during the 1960s and 1970s, were intimately linked to a new ideology of work and entrepreneurship which combined nationalism and pro-growth Confucian precepts. ${ }^{24}$ The figure below illustrates the links between the collectivist values, development policies and its results.

${ }^{21}$ C H Park, Korea Reborn: A Model for Development. Englewood cliffs, NJ: Prentice Hall, 1979, pp $60-62$.

22 E. Kim, and G. S Park, "Nationalism, Confucianism, Work Ethic and Industrialization in South Korea", Journal of Contemporary Asia, Vol.33.No.1, 2003.

23 J. S Kim, "1910-2010: from Colony to Leading Nation", Korea Focus, April, 2010, p 6, available from http:/ / www.koreafocus.or.kr/design2/features/view.asp?volume_id=96\&content_ $\mathrm{id}=102988 \&$ category $=\mathrm{H}$, accessed 15 August 2012.

24 E. Kim, and G. S Park, "Nationalism, Confucianism, Work Ethic and Industrialization in South Korea", Journal of Contemporary Asia, Vol.33.No.1, 2003. 
Figure 1 Influences of Collectivism on Korea's Early Development

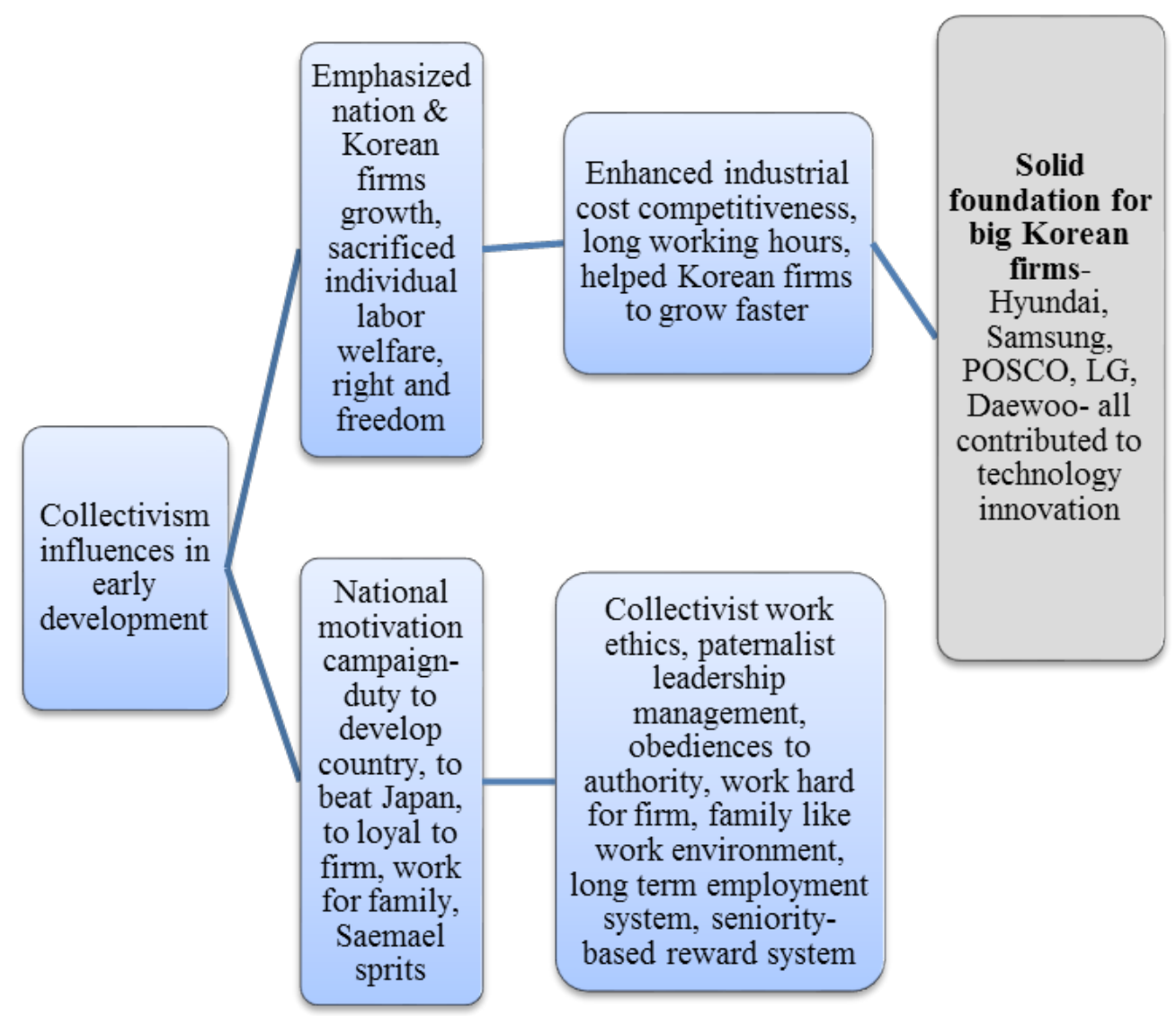

Source: Author's observations

The influence of the government in Korean societies has been strong and has actively engaged in the industrial development processes. The growth of chaebol firms was initiated and steered by the Korean government-led authorities. ${ }^{25}$ Several studies suggests that the role of the authoritarian state as being responsible for the creation of chaebol firms. ${ }^{26}$ One of the unique and common characteristics of Korean human resource management is not only authoritarianism but paternalistic leadership reinforced by a clear hierarchical order and vertical communication.

25 S. I Chang, "Study on Human Resource Management in Korea's Chaebol Enterprise: A Case Study of Samsung Electronics", The International Journal of Human Resource Management, Vol. 23, No. 7, 2012, p 1438.

26 B Cumings, "The Origins and Development of The Northeast Asian Political Economy: Industrial Sectors, Product Cycles, And Political Consequences", International Organizations, Vol. 38, 1984, pp 1-40; H Koo, "The Political Economy of Income Distribution in South Korea: The Impact of the State's Industrialization Policies", World Development, Vol. 12, 1984, pp 1029-1037; S Kang, Labor Movement in Korea, Seoul: Korea Labor Institute, 1998. 


\section{Korean Entrepreneur's Collectivism and Business Success}

Korean entrepreneurs, who laid foundations for the success of Korean industries and innovation, are among the country's patriots who have devoted themselves to the modern nation-making process when Korea was in extreme poverty. Park Tae-joon, who built the first steelworks in Korea, laid the foundation for Korea's heavy chemical industries and made POSCO the industrial giant that it is today. Chung Ju-Yong, the Hyundai group founder, built the first Korean cross-country expressway, exported the first Korean-made car, built the first Korean oil tanker, and the first Korean made ship. Lee Byung-chul and Lee Kun-hee, the Samsung group leaders, are described as paternalistic, hardworking and smart, and who exploited Korean collectivist spirit to motivate workers to be both productive and innovative. Many of the founding fathers of Korea's modern industry, worked in collaboration with the Park government to achieve national prosperity and overcome challenges facing the nation.

Korea in the 1960s was seen as a basket case, a country without capital, without technology, without expertise, but with an abundance of cheap labor. To remake Korea into an industrial powerhouse, Park Chung Hee believed that the state needed frontier entrepreneurs, who could help industries to succeed in the international market and to mobilize resources in an efficient way. Consequently, Park selected a few dozen firms which were given unparalleled privileges and government support to produce and export as much as possible. Among the entrepreneurs, Park Tae-joon, Chung Juyong, and Lee Byung-chul were the lucky frontiersmen chosen at that time. Although the choice of the candidates was based largely on Park's personnel preferences, their success in developing Korean industries globally proves that these choices were not made merely based on personal relationships. By providing capital and technology to a few select industries run by a limited number of business groups, Korea impressively transformed itself in record time. Without doubt, Korea's early entrepreneurs played a crucial role in the nation building process.

Early Korean entrepreneurs were often portrayed as frontiersmen, risk-takers, confident, and patriotic. They aspired not simply to amass personal fortunes; but to benefit the nation. They played their roles as the captains of industry by utilizing the limited resources Korea had to offer and producing the maximum output. They were seen as the embodiment of Korea's economic miracle and unprecedented transformation.

When the Park government decided to develop heavy and petrochemical industries, someone was needed to make the steel locally, and Park chose Park Tae-joon as the man for the job. In light of the extraordinary success of POSCO, Park Tae-joon was clearly the right choice. Park Chung-hee and Park Tae-joon shared the belief that industrialization was a national imperative if Korea was ever to be free from poverty, and as a means of improving the daily lives of the people and developing the national economy. ${ }^{27}$ Without steel, it would have been impossible to build ship, automobiles, bridges, and buildings. Much of Korea's economic infrastructure has been dependent upon steel. With no technology, no capital, and no expertise in 1960s, Park Tae-joon accepted the challenging task. Under the leadership of Park Tae-joon, POSCO produced 21 million tons of steel annually in his 25 years with the company (1968 - 1992), leading

27 Byung Chang, Yoo, "In Memory of Park Tae Joon, Founder and Former Chairman of Posco", Korea Herald, 19 December 2011, available from http://www.koreaherald.com/view. php?ud=20111219000848, accessed 28 June 2012. 
many to compare Park Tae-joon to America's Andrew Carnegie; whose steel production capacity amounted to only 10 million tons annually over 35 years. ${ }^{28}$ By 1998, POSCO was recognized as the world's leading crude steel production company.

To meet the growing need for self-developed technologies or technology independence, POSTECH (Pohang University of Science and Technology) and RIST (Research Institute of Industrial Science and Technology) were established. The FINEX steelmaking process, which is a cutting edge steelmaking technology, was developed by POSCO and commercialized globally, strengthening POSCO's position as a leading global steelmaker. The ability of POSCO to produce low-cost high quality steel made POSCO the "World's Most Competitive Steelmaker" for four straight years, as recognized by the World Steel Dynamics. ${ }^{29}$ Although POSCO today is already at the top of its game, it faces tough competition from Japanese and Chinese rivals. Therefore, POSCO must to work hard to continuously develop new innovative technologies.

The "make steel, serve the country" motto and the "turn right" philosophy are the mental foundations of POSCO which unified its workers since the company was founded in 1968. When Park built the Ilgwan steel mill in the Yeongil Bay in Pohang in 1970, he promised workers that he would make the mill a great success because it was built with capital allocated from the Japanese. ${ }^{30}$ If the business failed, he said he and the mill workers would drown themselves in the bay. The stress of using money obtained from Japan led the workers to exceed in the efforts and to produce more steel then anyone could have anticipated. Korean national pride was at stake and POSCO workers took it upon themselves to protect Korea's reputation. Encouraged by Park Taejoon's resolve, the workers devoted everything they had to finish the mill's construction six months ahead of schedule, taking only six month to complete construction. ${ }^{31}$ The story has become a legend in industry, showing how patriotism can motivate even the lowliest of workers to work day and night for the future of a nation. During his speech to employees, Park Tae-joon's remarked,

Why did we make this company? How have we developed this company? For our country to overcome poverty...Amidst the crisis due to the betrayal of the international consortium, we transferred part of the funds claimed from Japan for revival. If our company struggles because of the conflict between the labor union and management, this is against our duties to the people and ancestors... we cannot be content in being a company that stably supplies the rice of industries to Korea, or earning dollar through exports. Pohang Steelworks in the centuries to come must always be the best and most dignified compared to any steel company in the world. Our company has this

28 "Last Words Entreated, Become the Worlds' strongest POSCO", POSCO Press release, 20 December 2011, available from http://www.posco.co.kr/homepage/docs/eng2/jsp/ prcenter/news/s91c1010035p.jsp?idx=1936, accessed 10 April 2013.

29 POSCO Press release, available from http:/ / www.posco.co.kr, accessed 7 July 2013.

30 "POSCO Leadership Park Tae Joon", KBS World, 19 December 2011, available from http:/ / world.kbs.co.kr/english/program/program_economyplus_detail.htm?No=3142, accessed 30 June 2012.

31 "POSCO Leadership Park Tae Joon", KBS World, 19 December 2011, available from http:/ / world.kbs.co.kr/english/program/program_economyplus_detail.htm? $\mathrm{No}=3142$, accessed 30 June 2012. 
goal but it cannot be achieved without the proactive cooperation and participation of our employees. ${ }^{32}$

In 1978, during a visit to Nippon Steel's Kimitsu Works, China's Deng Xiaoping asked Yoshihiro Inayama, then the chairman of Nippon Steel Corporation, to build a steelworks company like Pohang Steelworks in China, but received a response that, "China doesn't have Park Tae-joon". This was an acknowledgement of Park's leadership. ${ }^{33}$ One of POSCO's employees -Yoo Byung Chang, ${ }^{34}$ who worked in the company between 1975 and 2010 observed that,

Park Tae Joon regarded workers as members of his family. He dreams during sleep, sweet or bitter, were all about the steel company. Overcoming all kinds of difficulties, he accomplished the mission of building two steel mills, in Pohang and Gwangyang in the shortest-ever time. Without POSCO, the Korean shipbuilding and automotive industries would not exist as they do now. ${ }^{35}$

The success of Korean firms cannot be attributed solely to the Korean patriotic spirit. The collectivist management style of Korean companies has played significant role in the success of many firms. Korean management culture is characterized as group oriented; centered on values of harmony and cooperation. Such values are frequently mentioned in corporate visions of almost $50 \%$ of Korean companies. Some of Korea's largest corporations, such as LG, Samsung, Hyundai, and SK demonstrate the importance of unity, cooperation, and devotion to work. Today, these companies are major contributors to the national innovation index. According to a study by Thomson Reuters, LG Electronics, Samsung Electronics, and LSIS are ranked among the top 100 global innovators. One thing these firms have in common is that they were established during Park Chung Hee's era, and slowly developed into the giant technological firms that they are today.

Under Korea's collectivist culture, the vertical top-down decision-making process gives rise to autocratic leadership, but it also enables quick decision-making with ideas coming from the top. For instance, Samsung group's President, Lee Kun-hee had extensive power in policy-making. When Lee Kun-hee suggested that Samsung invest in the automobile industry, although the idea was opposed by many among Samsung's Board of Directors, none voiced their opposition and ultimately the Board went with Lee Kun-hee's decision. This is different to the Japanese management style which stresses consensus. Hyundai Motor demonstrates similar leadership where subordinates unquestioningly obey and respond quickly to the requests of their leaders. For example when Hyundai Motor's chairman, Chung Mong-koo visited a distribution center in California, he noticed a large pile of remanufactured transmissions which

32 "Last Words Entreated, Become the Worlds' strongest POSCO", POSCO Press release, 20 December 2011, available from http://www.posco.co.kr/homepage/docs/eng2/jsp/ prcenter/news/s91c1010035p.jsp?idx=1936, accessed 10 April 2013.

33 "Last Words Entreated, Become the Worlds' Strongest POSCO", POSCO Press release, 20 December 2011, available from http://www.posco.co.kr/homepage/docs/eng2/jsp/ prcenter/news/s91c1010035p.jsp?idx=1936, accessed 10 April 2013.

34 Yoo, who worked closely with Park Tae Joon, held many positions, including being the president of POSCO America and CEO of POSDATA.

35 B. C Yoo, "In Memory of Park Tae Joon, Founder and Former Chairman of POSCO", Korea Herald, 19 December 2011, available from: http://www.koreaherald.com/view. php?ud=20111219000848, accessed 28 June 2012. 
had initially failed and needed to be rebuilt. Chung immediately called for everyone associated with the transmission design and quality control to assemble in California as soon as possible. As a result, 20 high level executives from all related divisions flew out from Korea to arrive in California within 24 hours. ${ }^{\square}$ This story demonstrates power of collectivist leaders, where subordinates are absolutely obedient to superiors and terrified of causing any offence.

Despite the strengths and weaknesses of the collectivist management style, collectivism has been the driving force behind the team spirit of Korea's corporate culture and has most certainly contributed to the growth of Korean firms and economy. Nevertheless, after Korea developed from a factory-driven economy to an innovationdriven economy, the problems inherent in collectivism became more apparent. The rigidity of the collectivist culture, which restricts free flow of communications and ideas started to undermine the growth of Korea's innovation in mid 1990s. To tackle the innovation growth problem, Korean entrepreneurs realized the need to change the corporate culture. Western management system was gradually adopted which promoted individual competition and reward system. Nonetheless, the influences of traditional collectivist values remain strong in the majority of Korean corporate management system.

\section{Conclusion}

Collectivism had worked very well in the initial stages of industrialization in South Korea. The collectivist work culture which stressed on loyalty, group harmony, discipline and self-sacrifice spirit enabled Korean firms to grow tremendously with the help of government pro-firm policy. Under the leadership of Park Chung Hee, industrial policies were completely collectivistic where national interest and industrial growth were given top priority. South Korean workers' welfare and rights were sacrificed to keep industrial costs lower, which helped industrialists to be cost competitive and enhance the nation's exports. The result was, South Korea successfully transformed herself to an industrialized economy within half a century. Korean conglomerates such as POSCO, Samsung group and Hyundai group all were established during this period. Under the "human cultural revolution" campaign of Park Chung Hee, the spirit of selfreliance, diligence, confidence and cooperative were promoted; the whole society was successfully mobilized with the help of powerful entrepreneurs. Korean entrepreneurs, such as Park Tae-joon, Chung Ju-yong, and Lee Byung-chul were the industrial pioneers who laid solid foundation of Korean industries. They all shared similar characteristic of collectivist leadership. To enhance the work commitment of workers, value of loyalty and cooperative sprits were emphasized. Long-term employment and seniority-based reward system were adopted where employees were treated like family members and the head of organization was like father to his employees. Korean organizations tried to make employees feel like family. In return, employees remained loyal to the company and their commitment to work became stronger. This collectivistic management culture worked very well to boost the growth of Korean firms. With disciplined and loyal workforces, Korean multinational firms were able to capture international market with their competitively priced products; however, in the long run it was sustainable, particularly after Korea achieved the status of an innovation-driven economy in the 1990s. 
After a few decades of development, the traditional vertical hierarchical structure, the resulting inflexibility of the employment system became an obstacle to Korean technological firms as it has started to show signs of slowing down in the decision making process and discouraging innovation and creativities. To sustain its dynamic growth, producing innovative and good quality of products was needed. The ability to offer cheaper products does not always guarantee success in a changing and highly competitive global market in the face of rising production costs in addition to the emergence of new business rivals such as those from China. Rigidity in the organizational structure and mechanistic cultures do not work well for innovative firms, because employee mobility would be limited; and not conducive to free flow of communication and new ideas. Flexible management or organic structure which allows quick decision making and free flow of new ideas are needed because innovation is about developing and implementing new ideas. During the 1997 global financial crisis, Korean industries faced intense pressures. Firms were forced to fundamentally rethink their business strategies and management system. Fortunately, Korean top firms such as Samsung Electronics and Hyundai Motor realized the need to change. They realized of the weaknesses of traditional collectivist type of management were not favorable for innovation-oriented industries.

Collectivism may worked well in the initial stage of industrialization which focused on manufacturing cheap products, however it does not guarantee better innovation. Globalization has imposed pressure on both the Korean government and companies to change. As a new knowledge-based society, Korean leaders and entrepreneurs realize of the need to adopt more individualist values. Nonetheless, changes of culture is difficult as Koreans are still dominated by collectivist values. Even though top Korean firms have adopted new management systems, the majority of Korean firms are still dominated by traditionally seniority-based culture and top-down hierarchical structure. Certainly, another cultural revolution is needed in facing rising competition globally, particularly from Chinese firms which continuously generate new threats to Korean industrial players. 
